The University of San Francisco

USF Scholarship: a digital repository @ Gleeson Library |

Geschke Center

Philosophy

College of Arts and Sciences

2017

\title{
Folding Nature Back Upon Itself: Aristotle and the Rebirth of "Physis"
}

Marjolein Oele

University of San Francisco, moele@usfca.edu

Follow this and additional works at: http://repository.usfca.edu/phil

Part of the Philosophy Commons

\section{Recommended Citation}

Oele, Marjolein, "Folding Nature Back Upon Itself: Aristotle and the Rebirth of "Physis"'" (2017). Philosophy. 58.

http://repository.usfca.edu/phil/58

This Book Chapter is brought to you for free and open access by the College of Arts and Sciences at USF Scholarship: a digital repository @ Gleeson Library | Geschke Center. It has been accepted for inclusion in Philosophy by an authorized administrator of USF Scholarship: a digital repository @ Gleeson Library | Geschke Center. For more information, please contact repository@usfca.edu. 


\title{
Folding Nature Back Upon Itself: Aristotle and the Rebirth of Physis \\ Marjolein Oele, University of San Francisco \\ moele@usfca
}

In: Ontologies of Nature: Continental Perspectives and Environmental Reorientations, eds. Gerard Kuperus and Marjolein Oele (2017), Dordrecht: Springer.

\begin{abstract}
:
"Folding Nature Back Upon Itself: Aristotle and the Rebirth of Physis," confronts us with nature's receding presence and proposes to think through a rebirth of physis. Following Aristotle's concept of physis, this paper locates two axes along which such a rethinking of physis can take place. The first axis is vertical, and turns around the fundamental tension that each natural being faces in seeking to overcome its own matter in order to reach transcendence. The second axis is horizontal, and follows Aristotle's ideas that physis cannot unfold unless aided, stimulated, nurtured and enforced by external factors such as one's environment, food, art, technology, and politics. This paper argues that vertical transcendence needs to be rethought to accommodate earthy, individual natural flourishing. Horizontal transcendence (e.g. rethinking the collaboration between different species and the collaboration between art and nature) may allow physis the kind of vertical transcendence that leads to its rebirth. This has important implications for both restoration projects and de-extinction projects: we need to acknowledge the role of human design for restoration and conservation projects, and envision humans no longer as external and superior to eco-systems, but as part of them. Only within newly conceptualized social-ecological systems can such a new vision of physis take flight.
\end{abstract}

To go back to Aristotle and his understanding of nature is to take a pause, breathe deeply, and let go. Beyond rhetorical embellishment, this exercise in mindfulness indicates that we need more than theoretical musings to take up the task of understanding physis. Not only do we need to go back to the meaning and definition (logos) of physis, of which the Latin "natura" and our "nature" are such awkward and stultified translations, but we truly need a new embodied way of perceiving and feeling if we ever want to get close to the meaning of nature. Perhaps pausing and breathing is not enough to get us there, but it would seem a helpful beginning for a 
(possible) re-birth of physis, the word that in its original Greek verbal form phyo literally means birth and growth (Aristotle, Physics II.1, 193b18; Sachs, 1998, 31). ${ }^{1}$

Of course we do not want to be naïve, and in this sense "letting go" is doubly effective: the question is whether we can truly let go of "nature," and listen to and return to physis and the concepts and way of life it embodies. Following Gadamer's hermeneutics, perhaps the best course of action is to bring our own prejudices into play and make them conversant with "the other"-even if, as critics of Gadamer have pointed out, a fusion of horizons remains illusory and idealistic at best (Costache, 2016, 107). ${ }^{2}$ But even if we do not "get" to physis-and have to let go of letting go-perhaps at least we will have learned to take some distance to our own prejudices, and to make them productive in rethinking our current framework. And this framework is desperately in need of radical conceptual and practical reconfiguration.

Glancing over our current prejudices regarding nature, we find a broad spectrum of images. Innocently, the romantic vision mirrors a wildlife documentary that shows the awe-inspiring struggles between different species. Religiously inspired, we might think of nature as a holy, transcendent power (Kant, 1987, B28, 119-120). ${ }^{3}$ Close to home, nature appears in the prosaic and day-to-day unfolding of our own human nature. Ethically and politically, we feel nature's corruption and demise breathing down our necks with unrelenting force: species extinction, accelerated climate change, rapidly melting poles, etc.

What perspective on nature is the strongest for our current age? I would argue that nature makes itself most powerfully felt in its receding presence, and the lingering image it leaves in its trace is that of its idealization as a pure, untainted, awe-inspiring force. Due to human interventions and increasing development, natural beings seem less and less able to express themselves. Even if plants and animals can survive amidst one of the greatest episodes of species extinction, then the question remains whether their presence is not merely a shadow of their natural existence. Plants, for instance, are mostly marginalized to contained segments such as backyards, farms or parks where they are closely watched and manipulated. Even while seed banks have emerged to "preserve" the kinds at risk, the very existence of such banks emphasizes that natural species can nowadays mostly live as pure potentialities: existing as absence (Agamben, 1999, 179). Paradoxically, the "successful" unfolding of human nature (as least in terms of quantitative population

${ }^{1}$ Hadot addresses the initial meaning of physis as process of growth and how this later transformed (Hadot, 2006, p. 17).

${ }^{2}$ One such critic is Jacques Derrida. In his book, Gadamer and the Question of Understanding: Between Heidegger and Derrida, Costache argues that for Derrida "philosophical hermeneutics [is] incapable to account for the alterity of the other" $(2016,107)$, since, at least according to Derrida, it is based on the assumption of perfect agreement.

${ }^{3}$ In his description of the awe-inspiring yet (potentially) destructive force of nature in the form of the sublime, Kant explicitly draws parallels between respect for nature and respect for the divine. 
growth) has brought us to the brink of this collapse, and it is unknown whether any theory or practice can reverse nature's receding presence.

How did we get to this precarious situation? Is there anything in the Greek concept of physis that foreshadows both nature's theoretical idealization and its practical demise? If so, how could a concept such as physis - associated with birth and growth - have led us in such a dire direction? Or is there something in the Greek concept of physis that has gotten lost in our modern era, and would its "revival" possibly offer some kind of "solution" to our current predicament?

This paper proposes an attempt to think through a rebirth of physis. The attempt for such a rebirth can only happen through rethinking the ontological beginnings of physis and making them conversant with our own prejudices. Following Aristotle's concept of physis, I accordingly locate two axes along which such a rethinking of physis can take place. The first one operates on a vertical axis, and turns around the fundamental tension that each natural being faces in seeking to overcome its own matter in order to reach transcendence into pure, divine, actualization. The second axis is horizontal, and follows Aristotle's ideas that physis cannot unfold unless aided, stimulated, nurtured and enforced by external factors such as one's environment, art, and politics. ${ }^{4}$ My thesis is that vertical transcendence needs to be rethought to accommodate individual, natural flourishing, and that horizontal transcendence (and specifically acknowledging the role of human design in restoration and conservation projects) may make it possible to allow physis the kind of (authentic) vertical transcendence that leads to its rebirth. In the following, I will first analyze physis on a vertical axis, after which I turn to the horizontal transgressions of physis and the possible implications that follow from this.

\section{Vertical transcendence: the ambiguity of physis and its (im)possible transcendence ${ }^{5}$}

That nature is, it would be ridiculous to try to show, for it is clear that among the things that are, such things are many (Aristotle, Physics II.1, 193a3). ${ }^{6}$

Very similar to our current use of the term "nature" as an umbrella term for many different natural beings, the starting-point of Aristotle's account of physis is the

\footnotetext{
${ }^{4}$ While especially the notion of art and politics seem mostly applicable to human nature, I extend Aristotle's model to include all of nature.

${ }^{5}$ A number of paragraphs of this section on vertical transcendence rely textually on my essay "Aristotle on Physis: Analyzing the Inner Ambiguities and Transgression of Nature" (Oele, 2018).

${ }^{6}$ This is Sachs' translation and emphasis. For the translation of Aristotle's Physics, I mostly rely on Joe Sachs' translation (1998), with some slight modifications if necessary.
} 
multiplicity of nature, gesturing at "nose, eye, face, flesh, bone, and in general, animal; leaf, root, bark, and, in general plant" as examples (Metaphysics VI.1, 1026a1). Still, while his approach of physis begins with the concrete realities of natural beings, his philosophy of nature, much like that of his teacher Plato, finds itself rooted in a true ontology of nature (Reale, 1990, 293) or a "proto-physics" (Höffe, 2003, 71): an examination into the very origins or sources (archai) of nature (Physics I.1, 184a16). ${ }^{7}$ Thus, an ontological conception of nature prominently asserts itself. And from the beginning, this ontological commitment is double, since nature itself is twofold:

But since nature is twofold, and is both form (eidos) and material (hylē), we must consider it as though we were inquiring about what snubness is (Aristotle, Physics II.2, 194a12).

The student of nature (the physikos) needs to examine both matter and form. The definition of snubness (simotēs) subtly exemplifies this juxtaposition, since a definition of snubness appeals to a definition of a form (concavity) that is only applicable to a certain kind of matter, namely the nose (Physics II.1,193a7). The fact that it was Socrates who was known for his snub nose emphasizes, through the example of snubness, that the study of physis is always rooted in the particularity of "this one" (tode ti) here and now and thus finds its ultimate context of meaning within the peculiarity of the living being it studies (Gadamer, 1980, 212).

Still, the important materiality of each natural being is ultimately subordinate in meaning to the importance of form, with Aristotle stating: "form is more physis than matter" (Physics II.1, 193b8). His reasons for this are multiple. First of all, in our colloquial speech we mostly use the term physis for that which has actually taken up a particular form, versus that which is only potentially of such a nature (e.g. the matter or flesh or bone). Secondly, human beings originate from human beings, indicating that this process is mostly ruled through the transmission of form, not matter. Finally, Aristotle alludes to the meaning of the root verb for

${ }^{7}$ According to Wolfgang Wieland, while it is clear that such a knowledge based on principles is necessary, it is never explicitly clear how such an inquiry into principles is attained. In Wieland's view, such an inquiry into principles is practiced more than theorized about (Wieland, 1970, 53). Provocatively, Heidegger, in his analysis of Aristotelian physis, argues that since the word "nature" always entails an interpretation of beings as a whole, and since metaphysics articulates the truth about beings as a whole, meta-physics is "physics" (Heidegger, 1998 [1939], 185. Nonetheless, Aristotle in various locations makes a distinction between first philosophy or theology and physics, thereby lending proof to the idea that the boundary between physics and metaphysics, while perhaps admitting of transgressions, needs to be carefully kept in view (e.g. Metaphysics VI.1, 1025b191026a32). Interestingly, in Nicomachean Ethics VI.8, 1142a16-18 Aristotle argues that discovering the principles of both metaphysics and physics requires experience, which is why young people can become mathematicians but not metaphysicians or physicists. 
physis, i.e. "to be born" or "to grow," explaining that just as growth is always defined by its endpoint (the "to which") instead of its beginning point (the "from which"), the meaning of physis is likewise to be found in the ultimate form that something has received rather than the matter with which it began (Physics II.1, 193b8-19).

The main role reserved for form in nature acquires more depth when brought in connection with self-actualization and self-preservation, especially in differentiation from motion (kinēsis) and alteration (alloiōsis). In De Anima, Aristotle writes that we need to distinguish processes of change and alteration in which deprivation and loss play a central role (e.g. moving from ignorance to knowledge through learning) from processes that "preserve (sōteria) that which is potential by something actual which is like it" (DA II.5, 417b4-5). Aristotle speaks of the latter processes as ones that "pertain to dispositions (hexeis) and nature (physis)" (DA II.5, 417b15-17). In the Metaphysics we encounter a similar thought: "the nature of a thing is a this and a disposition (hexis) into which it comes" (Metaphysics XII.3, 1070a12).

Nature in this latter sense represents a process of expressing and maintaining oneself completely at every moment, excluding change. But this account of physis as full self-actualization comes at a high price. By focusing on "completely active" processes as the center of physis, many other processes that make up the existence of natural beings seeking food, growing towards the light, adapting one's color to the environment, etc.- - are considered second-rate processes that cannot truly express the nature of these organisms. This myopia is highly problematic and limiting. Conceptually, it makes sense to distinguish a movement or change (such as the acquisition of color) from a sensory activity like seeing that is complete at every moment and has its own internal end (e.g. Metaphysics IX.6, 1048b23). However, the embodied existence of natural beings clearly depends upon the fusion of such processes. For instance, the process of a lion hunting an antelope (strictly speaking a kinessis) seems continuous with the goal of the lion eating it (strictly speaking an entelecheia). To separate the two would be artificial: the motion of hunting offers the embodied condition of the possibility for a living being's survival (soteria).

Thus, on a vertical axis, Aristotle's account of physis oscillates between two poles: a natural being moves between the "thisness" of matter associated with the particularity and individuality of herself, and the idea and universality of form, associated with transcending those finite conditions and reaching the ideal of (self) actualization. The fact is that, paradoxically, nature seeks the self-transcendence of natural beings: one needs to overcome one's own contingent and material natural being to fully be oneself. This emerges also clearly in Aristotle's idea that reproduction is the most natural function in all living beings-as it allows a natural being to share in the order of the eternal (aei) and the divine (theiou). In Aristotle's words, "all things yearn (oregetai) for that, and for the sake of it do everything that they do by nature (kata physin)" (De Anima II.4, 415a30-415b3). In reproduction, one transcends the numerical, existential self so as to continue nature qua nature. ${ }^{8}$

${ }^{8}$ Aristotle writes about this process: "enduring not as itself but as one like itself, that is one with it not in number but in kind (eidos)" (De Anima II.4, 415b7-8). My translation here is based partly on Hett (1995) and partly on Sachs (1999). 
Hence, the preceding analysis uncovers, at the heart of Aristotle's explanation, an irresolvable tension. On the one hand, Aristotle's ontology of physis is dedicated to the very singularity of natural beings and their composite grounding in both matter and form. Simultaneously, his ontology of physis has ambitions beyond the here and now: his equation of physis with form and its activity-active completion and self-realization-ultimately finds nature suspending and transgressing itself, at least, or insofar as, this means the overcoming of the contingency, materiality and individuality of physis. This leaves us to ask: what would nature mean if it leaves the natural, disconnecting from the subjects whose realization it is? Acknowledging the problematic nature of this vision, it seems that nothing but a death certificate of physis needs to be signed given the abandonment of the very beings it would imply.

A possible way out of the enigma would be to situate physis in those fleeting moments of self-actualization in which a natural being fully lives: those moments in which life folds back upon itself and embraces itself. Moments analogous to those which Nietzsche describes as the moments of life affirming itself. And if the examples in Aristotle's Magna Moralia do any justice and are any indication, these are moments of pure fulfillment, processes of being-at-work that enclose their ends within themselves. Within the context of human life, Aristotle cites playing the flute as an example: "to the flute-player the activity and the end are the same (for to play the flute is both his end and his activity" (Magna Moralia II.12, I211b29-30). Extending this example to the broader context of natural life, Aristotle would agree that processes such as nourishment and perceiving similarly contain moments of self-actualization where a natural being both maintains and expresses itself fully.

Thus, the tension central to Aristotle's philosophy of physis, consisting of nature seeking to overcome its own particularity by transcending into the divine, might be amended by rethinking physis in the following way: perhaps Aristotle's vision of vertical transcendence does not so much aim for actively taking leave of the here-and-now, but instead seeking to carve out space for true moments of selfrealization, moments in which nature folds back upon itself and embraces itself - be it through growth, nourishment, perception, etc. The most important question this raises now is: what happens when we bring these Aristotelian presuppositions about physis into play with our own current presuppositions about the world? In what way does Aristotle's conceptualization of physis foreshadow the theoretical idealization of nature as we currently see it, as well as its practical demise? And how could we possibly allow for a rebirth of physis?

The "idealization" that is nature is, as I tried to argue for Aristotle, only shortlived in the natural world-there are only moments of pure nature realizing itself, but they are embedded in our embodied world, and eventually give way to corruption, demise, disability and death. In other words-the "ideal" nature has always been fragmentary, fleeting in its pureness, and not in our possession Physis' fleeting character as described by Aristotle resonates strongly with our own views of nature, as we similarly "long" for a nature that we cannot capture. A current artist who speaks to this fleeting character of nature's self-realization is Andy Goldsworthy. The materials of his Snowball Drawings are based on snowballs mixed with pigments of seeds, with the snow melting on paper and leaving a trace. "What 
is left behind when the water is gone is a patterned history on the earth of nature's impermanence, a brief record that is here for a while but certainly not forever." ${ }^{\prime 9}$

Aristotle seems to believe in honoring the true moments of physis realizing itself, no matter how transient. Where have those moments gone? Where can we observe nature in its most "pure" moments-plants growing and nourishing themselves, animals in the grip of perception, humans dancing to the beat of the sounds echoing from the stones of Stonehenge? When we look to our own human lives, we must admit that these moments of pure, natural, self-actualization have radically diminished if not disappeared altogether in the context of modern society. Due to significant technological, social and medical progress, we should theoretically have more time, to pause, let go, and "be in the moment." In reality, we have less time to enjoy these pure "natural" moments of self-fulfillment. Instead of exercising self-realization, we find ourselves rushing from one thing to the next, enacting kinēsis far more than any sense of entelecheia.

In examining nature as a whole, we must realize that humanity's technological agricultural advances have resulted in a major suppression of the selfactualization of nature. For instance, we easily rip out a pioneering plant such as a thistle (a so-called "weed") before it can actually do its work and grow, die and enrich the soil to prepare it for other plants. Old, time-proven techniques, such as allowing land to lie fallow and restore itself without human intervention (Xenophon and Pomeroy, XVI.13) ${ }^{10}$ have for many years been abandoned to only recently acquire a bit of a revival. Meanwhile, synthetic fertilizers (that are supposedly better for soil enrichment) are widely used instead, commonly leading to water pollution and subsequent algae blooms. These new fertilizers cause dangerous "dead zones" where hardly, if any, life can take root. ${ }^{11}$ Thus, in humans' desire for a more efficient, productive, so-called "better" nature, we have, as a by- or after-effect, paved a much more destructive path. This destructive path may allow for a few living beings (such as the intended crops or the accidental algae population) to survive, but at the expense of many other (often indigenous) populations. Thus, whereas Aristotle envisions the path of physis as one leading to moments of pure self-fulfillment, we find that most current "standard" agricultural practices lead towards the polar opposite of this idea of nature's self-unfolding.

Still, perhaps we could argue that a few species truly do flourish due to agricultural interventions, as seems to be the case for mono-crops such as corn or soy. Yet, as scientists have pointed out, practices such as mono-cropping actually make the respective crops more vulnerable to diseases, ${ }^{12}$ prompting the use of commercial insecticides or the introduction of GMO's (Goodall, 2005, 39).13 And

${ }^{9}$ Curator description, Hess Collection, Napa Valley. Andy Goldsworthy. Snowball Drawings, Earth and Snow, 1993, 9 individual drawings.

${ }^{10} \mathrm{Cf}$. Xenophon, Oeconomicus XVI.13 for such proven techniques of having land lying fallow and how this procedure may compensate for the lack of manure.

${ }^{11} \mathrm{http}: / /$ www.sustainabletable.org/804/industrial-crop-production

$12 \mathrm{http}: / /$ www.sustainabletable.org/804/industrial-crop-production

${ }^{13}$ Jane Goodall, in Harvest for Hope, discusses the introduction of monocultures after WWII with the same crop being planted on the same field year after year. The focus 
even the farmers involved in such practices seem severely affected by it: those who maintain such crops are shown to be more prone to depression and suicide (Goodall, 2005, 39).

Speaking in more philosophical terms, it seems that monocropping replaces the vertical transcendence contemplated by Aristotle with a perverse version of Nietzsche's "eternal repetition of the same." Monocropping eradicates biodiversity for the sake of yield for a few who are nearly eternally successful, relying on the false interpretation of eternity as a monotonous, endless duplication of finitude. This perception fails to instantiate the embrace of a moment of life coming full circle, becoming, precisely as momentarily, vertically transcendent to itself. Thus, monocropping denies eternal recurrence, as it is defined by Elizabeth Grosz, i.e. that it "repeats the random event that lives only by being willed again, by being actively chosen while passively bestowed" (Grosz, 1999, 5).

Thus, due to human influences, the uniqueness and self-unfolding that is nature's own seems to increasingly withdraw and, with it, the opportunity for vertical transcendence. This withdrawal deserves recognition, and warrants a closer look at the ontological beginning of physis. As noted before, Aristotle finds in the Physics that the meaning of the root verb for physis, "to be born or to grow," is mostly defined by its end point (the "to which") than its beginning point (the "from which") (Physics II.1, 193b18-19). But, zooming in on our current age: what if these natural end-points have mostly disappeared, or have become mere illusions that can only be chased but never realized? Considering current contexts of radical species extinction and loss of biodiversity, inverting the relationship of teleology seems warranted on practical grounds alone insofar as physis lives far more prominently these days in the "from which" (living or dying as potentiality) rather than in succeeding towards the "to which." Moreover, inverting the relationship might be ethically warranted too, insofar as it allows us to do justice to the particular materiality that is physis.

Is Aristotle's conception of physis in some way responsible for our current predicament? If we follow the interpretation of physis as nature folding back upon itself, then I think not. Because what this interpretation gives us is a sense of the inner unfolding and embrace of nature that deserves respect. However, if we follow the trajectory of form being more important than and superseding matter then, perhaps, Aristotle and the subsequent tradition is partly to blame for our environmental troubles, insofar as thinking through the hegemony of form in abstraction from the matter allows for a worldview in which super-organisms can flourish that seem somehow divorced from their inner materiality and their own limitations, without any space for contextual consideration and health. In this way, the emphasis on form has created a perspective in which humans are ideally mostly thinking beings divorced as much as possible from their materiality. And, analogously, the most successful non-human natural beings such as soy and corn are known as highly successful natural growers, but without truly succeeding in feeding

to keep this one crop alive is taxing, and provides additional incentive to add chemical fertilizers and chemical pesticides. What results is high stress and elevated risk of suicide among farmers (Goodall, 2005, 39). 
those it needs to feed sustainably and healthily, as argued by Foley in Scientific American (Foley, 2013). ${ }^{14}$

How would rethinking physis reassert materiality and potentiality without reinstating a teleology of forms? It would do so by reimagining forms not necessarily on the basis of pre-given goals, but reconceive the origin altogether, using the current state of nature's materiality and potentiality as a point of departure. Accordingly, the task becomes to think of these potentialities as harboring their own forms within them, much in the way that Aristotle in a remarkable passage seems to suggest, writing that "matter is like an eidos" (Physics II.1, 193b19-20) and also indicating that "matter is almost, and in a certain respect is, an ousia" (Physics I.9, 192a7-8). Putting the radical, generative side of potentiality to the forefront-in terms of how it invites and resists certain actualizations-will be crucial in moving forward to reconceive the activity of nature in its powerful beginning. Accordingly, we need to be resourceful in finding ways to discern materiality's own yearning for, or resistance towards, certain forms. But the beginning should be made from here, and no longer from afar, to here.

In the next section, the paper will offer an analysis of how nature, for Aristotle, always horizontally transcends itself-needing the other (as in, for instance, the medical art or in human design). The thoughts postulated along this horizontal axis will provide a medium for rethinking a new kind of vertical transcendence, one which might set potentiality free for reclaiming itself and physis.

\section{Another Beginning for Physis: the (Re)Birth of Physis in Collaboration with Human Design}

On the brink of ecological collapse, surrounded by environmental disaster, the concept of physis has no place to go but to linger as a pure dream, an idealization moving through tarnished skies as an untainted, illusive, awe-inspiring force. In dreaming of a different future, a remote past or an alternative present, the physis we imagine is untainted and wild: the absolute other from technology, civilization and culture. Sickened by society, we occasionally leave our acquired luxuries and cellphones behind, pitch a tent in a remote field, and simply-listen to the sounds of birds and look at the stars at night. Here, we imagine, nature was once found. We

\footnotetext{
14 "The corn crop is highly productive, but the corn system is aligned to feed cars and animals instead of feeding people." And when corn feeds people, it mostly "feeds" them in terms of high fructose corn syrup. See Jonathan Foley, "It's Time to Rethink America's Corn System. Only a tiny fraction of corn grown in the U.S. directly feeds the nation's people, and much of that is from high-fructose corn syrup."
} 
desperately, nostalgically, seek to turn and return to nature, by turning away from technology and civilization (Cronon, 1996, 70, 72).15

This burning quest to invoke nature by temporarily "giving up" our connections to society and technology speaks to an assumed fundamental ontological opposition: that between nature and its other(s), either in the opposition of nature and society, or nature and technology, or, for that matter, in many more fundamental oppositions. Many references could be given to illustrate the point that the understanding of nature seems to depend on the distinction with that which is not nature (Wieland, 1970, 231). ${ }^{16}$ For instance, despite Heidegger's attention to the oppositions within which nature is placed, we could equally criticize his own view of technology, which argues that the technological worldview approaches nature as a resource, making it part of a "standing reserve" to be manipulated and used up (Heidegger, 1977, 322). Or we could follow a more politically driven philosopher such as Hobbes to argue that the formation of society takes leave of "the state of nature" and does so for good reasons. Throughout the history of philosophy, we find such oppositions resounding, and amongst the ancient Greeks Aristotle himself is responsible for this kind of oppositional thinking, arguing for the opposition between nature and art (technē) (Physics II.1) as well as articulating the differences of lives based mostly on physis (those of animals) with those based ideally on logos (the lives of human beings) (Politics VII.12, 1332b1-2).

However, the proposed separation between nature and its other-in the form of techne, nomos, society, etc.-cannot and should not be maintained, as theorists such as Derrida $(2005,109)$ and Agamben $(1998,7)$ have pointed out. ${ }^{17}$ For, the very definition and function of each concept is based upon its exclusion from the other, and thereby fundamentally-informs the other. As Latour stipulates with regard to the oppositional dynamic between nature and politics in his work Politics of Nature: "conceptions of politics and conceptions of nature have always formed a pair as firmly united as the two seats on a seesaw" (Latour, 2004, 28). The ethical instinct to erase such divisions can be powerful, since it is only through rethinking these oppositions that we can try to form a new politics of nature that tries to do justice to nature's pluriformity and its intrinsic collaboration. The physis that we seek to invoke is thereby not pristine, unified; it is not other than society or technology. Rather, the physis to be sought is the result of collaboration, not outside anthropomorphism but also not solely anthropocentric. Historical investigations confirm such a collaborative perspective. As Cronon writes: "In fact, everything we

15 William Cronon traces the idea of opposing nature as pristine, untainted wilderness vs. humanity back to the end of the $19^{\text {th }}$ century. Before that time, wilderness was associated with what is barren and desolate, a "waste." Only with Thoreau, and other such as Muir does wilderness reach the status of being God's own temple (Cronon, 1996, p. 70, 72).

${ }^{16} \mathrm{Cf}$. Wieland, 1970, p.231. See also Heidegger, who lists some of the dichotomies in which nature functions: "nature and grace (i.e. super-nature), nature and art, nature and history, nature and spirit" (Heidegger, [1939] 1998, 183).

${ }^{17}$ In Homo Sacer, Agamben defines bare life as "that whose exclusion forms the city of men" $(1998,7)$ 
know about environmental history suggests that people have been manipulating the natural world on various scales for as long as we have a record of their passing" (Cronon, 1996, 83). Moreover, such historical perspectives confirm that moral injustice has been committed in the name of preserving nature's presumed purity, for instance by forcefully removing native inhabitants such as Native Americans from designated wilderness areas (Cronon, 1996, 79).

These contemporary insights are crucial to our progression. What I propose to do here is to move us forward by returning to Aristotle's concept of physis and discern exactly where the theoretical tools lie for constructing such an integrated view of non-human-nature-human collaboration. While Aristotle certainly provides tools to distinguish nature from its other, there are also important passages where he articulates their collaboration, specifically in his formulations of the connection between physis and technē. By highlighting such passages, I aim to expose that the very underpinnings for a strict distinction between nature and its other have been undermined from the very beginning, and that the history of philosophy, and certainly in the figure of Aristotle, holds important keys to an alternative beginning of physis.

This vertical rebirth of physis is dependent upon physis horizontally transcending or exceeding itself. Only in this way can we allow the potentiality that is central to physis to be regenerated, as we provide innovative ways to support and accommodate it. Here, thinking through "new forms" that accommodate the newdamaged, restructured-materiality of physis is crucial. Specifically, there is a task here to think through humanly designed restoration projects that, through human intervention, try to do justice to and respect the distorted, new materiality of nonhuman nature. Thoughts on the role of human-designed forms in accommodating the new inner logic of physis will offer a transition to additional thoughts on what a possible new politics of nature might entail. Thus, I will try to show that how, only by improving the horizontal levels of transcendence, the "vertical" level of transcendence (discussed in Section One) might become possible.

\subsection{Nature and Technology}

In Heidegger's considerations of technology, he argues that technology is oppositely placed to physis, and radically distinguishes it from art, technē. While art, as he understands it, makes it possible for physis to show itself, he argues that technology merely obfuscates this (Brogan, 2006, 48). ${ }^{18}$ Here, art's creative ability for allowing physis to come forth contrasts starkly with the modern, technological worldview that merely objectifies nature, and makes it part of a standing reserve to be manipulated and used up. Modern examples such as the use of the technology of "fracking" speak to this idea, as it literally fractures shale rocks, extracts natural gas, then leaves behind toxic fracturing fluid that subsequently contaminates ground water, soil and air.

18 It obfuscates this as disinterested worldly disclosedness, subjective domination and infinite repetition. Cf. Brogan, 2006, 48. 
Yet, my reasoning here is not to simply repeat this Heideggerian framework. Rather, I would like to think through ways in which technology might find itself again rooted positively in art (technē) in the Aristotelian-Heideggerian sense, and in that way allow for nature's supplementation and flourishing. I will argue that this is indeed crucial for our current world and its inundation of ecological destruction, and specifically when it comes to ways to think about technology's role to bring about ecological restoration. Before I do so, this argument first demands that we clarify Aristotle's ideas about the difference between physis and techne, and their possible collaboration.

For Aristotle, the opposition of physis versus techne does a lot of work, as it enables him to explain what each is, while depending upon the opposition with the other for its meaning. In the important opening passages of Book II of the Physics, the opposition between physis and techne allows Aristotle to carry through his main point, that natural beings have an innate impulse (hormē) of change (Physics II.1, 192b19-20) while those beings that are by art lack such impulse. The initial examples given - a bed, a cloak - are simple, everyday use items, likely made of "natural" materials such as wood or cotton, but nonetheless exemplary of that which stands outside of nature.

But do they really? A closer look at the examples given should give us pause. Perhaps beds and cloaks could be said to stand "outside of nature," although Aristotle himself seems to question this at least in part, contemplating Antiphon's suggestion that a bed, once buried and rotten, has the potential to sprout and become wood (Physics II.1, 193a13-14). The active force of the bed sprouting up as wood disrupts an all too easy opposition between physis and techne and if we thnk further about the examples, more problems emerge. A coat may be merely a cultural accessory, but in certain climates or seasons it may be truly necessary to protect human nature from the elements. In that way, while the origin of the coat is not natural (or partly natural in its materials), in its function it extends nature by enfolding and protecting it. Similarly, a bed may aid nature by providing us the comfort to sleep and restore ourselves. Still, while these examples may inspire some unease with a radical opposition between physis and techne, it is the next paradigmatic example that truly undoes a strict opposition: the medical art.

Aristotle introduces medicine as an art and tries to show that its way of healing is externally imposed, even if the patient happens to be a doctor (Physics II.1, 192b26). Still, if we think about what medicine does, we have to realize that its success is dependent upon an understanding of the natural processes that allow for a healthy body, and somehow promoting those natural healing processes-"turning them on"-to bring health about.

Can the medical art heal without nature? Even the most up-to-date, technologically wired, modern-day doctor would deny this. Surely, medicine can aid, rescue, and keep a body alive, but fundamentally it remains only a complement, or supplement (Baracchi, 2008, 13), ${ }^{19}$ to the living being's own natural healing

${ }^{19}$ Baracchi speaks of ethics as concerning what is "necessitated by nature but remains within the compass of nature as its complement, or, better, supplement" (Baracchi, 2008, 13). 
processes. Aristotle's text offers us reason to say that not only medicine, but art in general can allow for nature to complete itself, especially in those circumstances where nature somehow is unable to do so on its own. As Aristotle writes: "[a]nd in general, art (technē) in some cases completes (epitelei) what nature is unable to finish off, but in others imitates (mimeitai) nature" (Physics II.8, 199a15-16). In her helpful commentary on this passage, Baracchi notes: "While clearly irreducible to one another, the poiesis of tekhne and that of phusis cannot simply be understood as starkly separate. Rather, tekhne should be understood as ultimately belonging in phusis, completing phusis there where phusis seems to allow for an unregulated margin of indeterminacy, or there where its directives are not legible" (Baracchi, $2008,184)$.

So far, these Aristotelian reflections seem mildly interesting, if only for clarifying that a radical opposition between physis and techne cannot be maintained, certainly not in those situations where, as Baracchi claims, there is an "unregulated margin of indeterminacy" or where, as other commentators have clarified, nature provides "a kind of indeterminate foundation"(Ward, 2005, 296) ${ }^{20}$ that needs to be properly affected. Speaking more emphatically then, techne is not necessarily what obscures physis, but what can bring it out. With this in mind, Heidegger speaks in "Building, Dwelling, Thinking" of technē as rooted in tikto- "to bring forth or to produce", resulting in techne to mean: "to make something appear, within what is present, as this or that, in this way or that way" (Heidegger, 1993, 361). In Brogan's words: "the difference between physis and technē indicates a fundamental complicity. Aristotle needs the discussion of technē in order to accomplish the authentic disclosure of the being of physis, because this ability to be taken over, this being-able to be other than it is, belongs to the nature of beings from physis" (Brogan, 2006, 49). ${ }^{21}$ Ultimately, then, Heidegger in his rereading of Aristotle can paradoxically say that it is art that can let nature show itself, thereby overturning the long history of philosophy arguing that art is always secondary to nature. No longer is art subordinated to nature (Sallis, 1994, 107), not even to the truth of nature. Art is one of the ways in which truth happens (Sallis, 1994, 108).

\subsection{Nature, Technology and Restoration}

The above thoughts on the role of art for nature's revealing, expression and completion acquire poignancy and urgency once we consider the deeper philosophical resonance and application for our current age. Amid the disasters of ecological destruction caused, to a large part, by technological and social "advances," it seems intuitively necessary that a turn to nature should imply a turn away from

${ }^{20}$ Ward speaks of physis in this way particularly in the context of the emergence of the virtues.

${ }^{21}$ Brogan continues: "Techne is possible precisely because it attends to this negativity at the heart of natural beings, and brings forth beings by allowing this force of negativity to be revealed" (Brogan, 2006, 47). In this regard, technē is possible "because it is an awareness of this fundamental relationality that belongs to beings" (Brogan, 2006, 49). 
technology and human agency. Certainly, this seems true to the extent that we might want to move away from destructive human-designed techniques that mostly leave the earth in shambles -including contaminated groundwater, producing toxic fumes, etc. Still, we could argue that it is not so much the technology that is harmful as such, but the relationship (Higgs, 2003, 185) that this technology has to nature and the beings in it. Surely, there is a difference between a technological overtake of nature, merely seeing it as a resource, and technology finding a way to actively engage with and restore nature. Because of (romantic) ideas that nature as wilderness is the complete other, we might be tempted to call any use of it an ab-use. But, as Cronon urges us, "we need an environmental ethics that will tell us as much about using nature as about not using it" (Cronon, 1996, 85).

In his book, Nature by Design, Eric Higgs pleads for such an environmental approach, which sees design ${ }^{22}$ as central to nature restoration: "rather than burying human agency behind a wall of ecological justifications, design acknowledges that restoration is also and always about people working with and within natural process" (Higgs, 2003, 14). By acknowledging the role of human agency in restoration, we honestly account for the unmistakable and unavoidable role of human interpretation of restoration, without denying that restoration designers ideally should be "pushing beyond human interests to meet the implicit demands, patterns, and character of ecosystems" (Higgs, 2003, 283). Prominently, we need to realize that "restoration is an intervention in natural process; the greatest and most demanding challenge is to figure out how our actions, our designs, can work alongside natural processes" (Higgs, 2003, 284).

A case in point in Higgs' study is Jasper National Park. Due to traditional values of wilderness, the landscape has become a "freak landscape, one out of character with the long-term ecological and cultural history of the region" (Higgs, $2003,55,36)$. This is due in large part to fire-suppression policies, which have led to a "staggering load of flammable material" and "the valley bottom, which previously resembled a complex guilt of grasslands, forest, and savannas, is now almost a carpet of green trees" (Higgs, 2003, 33). Also, after extirpation and reintroduction of elk, but without their historical predation, the population of elk has surged "to what some believe to be historically high levels" with resultant threat to "integrity of browse vegetation such as young aspen trees" (Higgs, 2003, 34-35).

What is needed, then, is a re-articulation of restoration, which is classically defined as "the process of assisting the recovery of an ecosystem that has been degraded, damaged, or destroyed." 23 While this definition focuses on repair, one should realize that, in our current predicament, there is no "return" possible to an original state. Rather, what can be hoped for is bringing about a certain health to a distorted ecosystem, and rethinking what such "health" might consist in for a system

22 The writers of Synthetic Aesthetics: Investigating Synthetic Biology's Designs on Nature point out that "design itself is part of the production system that is in crisis, preventing sustainable, ethical, and imaginative innovation" (Ginsberg et al, 2014, $\mathrm{xxi}$ ). Ginsberg pleads for reinventing design as biology is reinvented.

${ }^{23}$ Society for Ecological Restoration. 2002. Official definition. www.ser.org. Accessed 9 May 2017. 
that is chronically (if not terminally) ill. Here, Aristotle's ideas on the interaction between physis and techne may assist, even though his ideas mostly pertain to individual natural beings and not to eco-systems (Foster, 2002, 414). ${ }^{24}$ Specifically, his ideas on medicine are worthwhile, as he sees it to be the paradigmatic example of an art that works "by completing (epitelei) what nature is unable to finish off" (Physics II.8, 199a15-16). If we read the phrasing very carefully, and specifically the verb epitelei, then the goal is to bring physis towards (epi) an end (telos). For the chronically or terminally ill, this telos will not be flourishing, and needs redefinition. What may be brought about instead, as telos, is not a recovery, but a resilient way of coping with illness, i.e. a sustained way of living with and through an illness.

On a physiological level, one of the most promising, innovative medical therapies that aids in coping with an illness is immunotherapy, entailing fortification of patients' resilience by boosting their immune system (either in a general way, or very specifically by targeting particular kinds of cells). The way this works is not by imposing an external form upon the body (e.g. imposing "health" in the classical definition of a healthy, "normal" living being), but by reinforcing existing material forces within the inner logic of the body itself. The goal, "health," can accordingly be individually determined, based on how well a certain body can live through and with an illness. The goal of the medical art "working towards the end" (of health) can accordingly be recalibrated according to the particular strengths and weaknesses of the body.

On the basis of this example, it might be possible to reimagine innovative restoration practices that operate on a similar basis, and exactly by boosting the resilience of an ecosystem from the inside out, following the inner material logic of the ecosystem itself. And, similar to how some of the aforementioned medical therapies do not necessarily return the chronically (or terminally) ill patient to a previous status of health, but to a newly calibrated equilibrium of healthily-livingwith-and-through illness, the task of restoration is to encourage active management of ecosystems and "return them to health in whatever ways health is defined" (Higgs, 2003, 21).

To support the resilience of an ecosystem, special attention needs to be paid to biodiversity and redundancy. There is evidence that "suggests that systems with many different components are generally more resilient than systems with few components. Functional redundancy, or the presence of multiple components that can perform the same function, can provide 'insurance' within a system by allowing some components to compensate for the loss or failure of others." 25 The enhancement of biodiversity can occur through "maintaining structural complexity

${ }^{24}$ Foster addresses this fact, and tries to retrace within what category Aristotle would classify an eco-system. Based on the fact that it does not have an inner cause of motion or rest, Foster classifies an ecosystem accordingly as an "artifact." She argues that "like an artifact, the biosphere has instrumental value for the beings that inhabit it" (Foster, 2002, 414).

25 Applying Resilience Thinking. See: www.stockholmeresilience.org 
in landscapes, establishing buffers around sensitive areas, creating corridors for connectivity and controlling overabundant invasive species."26

Simultaneously, reimagining the place of human activity in processes of natural restoration should also open a wider perspective, one where nature acquires a fuller perspective along all of its cultural boundaries. Accordingly, as Cronon writes: "Our challenge is to stop thinking of such things according to a set of bipolar moral scales in which the human and the nonhuman, the unnatural and the natural, the fallen and the unfallen, serve as a conceptual map for understanding and valuing the world. Instead, we need to embrace the full continuum of a natural landscape that is also cultural, in which the city, the suburb, the pastoral, and the wild each has its proper place" (Cronon, 1996, 89).

The human role thus reimagined has to take into perspective the flux within which the natural world is, and reset its goals in relationship with the inner workings and potential of the natural world. Resonating with the cultural and natural history of a place and its native inhabitants, the way forward is to acknowledge humanity's own role and admit the intentional character of its design. Happy surprises may emerge within such natural-cultural designs, such as the latest scientific discovery that the soil of New York City's Central Park is host to an astounding diversity of microbes, mirroring soil conditions in many different parts of the world, such as deserts, rainforests, prairies and temperate forests (Ramirez et al, 2014). Additionally, among places deemed naturally "sublime," one can be surprised to learn of the level of design that has gone into reinforcing such sublimity, such as the careful and repeated framing and designing of the surrounding landscape of Niagara Falls (Spirn, 1996, 95-96). ${ }^{27}$

If it is the case that design stands in service to the other (Calvert, 2014, 211) then within the current era human design should stand in the service of trying to bring about nature's restoration. In this endeavor, design has to be mindful of operating within a narrowly defined margin, carefully allowing to bring out nature's potentiality through design, without overreaching and merely manipulating for the sake of manipulation. ${ }^{28}$

${ }^{26}$ Applying Resilience Thinking. See: www.stockholmeresilience.org

${ }^{27}$ As Spirn discusses, the falls and its surrounding landscape have been repeatedly reframed and redesigned and its water flow has been altered.

${ }^{28}$ In a similar vein, analyzing the potential and danger offered by synthetic biology, Ginsberg writes that "thinking in more detail about what it means to design biology well could help to avoid repeating past mistakes, like the unintentional spread of genetically modified variants and their knock-on effects, both social and environmental" (Ginsberg, 2014, 107). 


\section{Concluding Remarks: The Rebirth of Physis in Social-Ecological Systems}

The previous section showed, on the basis of Aristotle's texts, that from the beginning physis has horizontally transcended its own borders, and that art (technē) and design crucially belong to and may complete physis. This is a key insight for our current age, where the deplorable state of nature's demise seems to be a cry for ethical intervention that may allow nature increased resilience while boosting its potentialities. The human design envisioned above can, however, only operate within a radically different economic and political vision: one that substitutes a focus on promoting maximum efficiency (for humans) with one that is focused on resilience of every natural being involved, which "encourages policies that can better cope with ecological, market or conflict-related shocks." ${ }^{29}$ Here, the focus is on the unmistakable need for change, the rethinking of potency, and how to allow beings to deal with unexpected changes. ${ }^{30}$

Moreover, the proposed, ideal interaction between nature and human design can only truly take place within a modified vision of an ecosystem: one wherein humans are no longer seen as external and superior to it, but as intrinsic and subordinate parts of it. ${ }^{31}$ In this fashion, many authors supporting this kind of approach no longer speak of ecosystems, but rather of social-ecological systems.

When it comes to this kind of system thinking, Aristotle's conceptions of physis and his thoughts on politics seem remarkably far-flung and inapplicable. For, within his thinking of physis there is a focus on individual natural beings (plants, animals, humans) and within his writings on politics the focus is predominantly on the human being; consequently, the thought of promoting a new eco-system or a social-ecological system seems very remote to Aristotle's thinking. Still, the beginning of Aristotle's Politics may give us a hint of how, even given those limitations, nature always assumes social collaboration, thus foreshadowing the possibility of a new social-ecological system. For, as he sees it, the building blocks of a polis are not singular persons (as they are for modern thinkers such as Hobbes and Rousseau) but pairs: "First then, those who cannot exist without each other necessarily form a couple, as female and male do for the sake of procreation (they do not do so from deliberate choice, but, like other animals and plants, because the urge to leave behind something of the same kind as themselves is natural) and as a natural ruler and what is naturally ruled do for the sake of survival" (Politics I.2, 1252a26-31).

This passage is ethically compromising, but also holds promise. Its problematic content consists how it determines gender dynamics as fundamentally unequal, determining that the male should rule the female (Politics I.5, 1254b14-15).

29 "Applying resilience thinking; seven principles for building resilience in socialecological systems" (5). See: www.Stockholmresilience.su.se.

30 "Applying resilience thinking; seven principles for building resilience in socialecological systems" (5). See: www.Stockholmresilience.su.se.

31 "Applying resilience thinking; seven principles for building resilience in socialecological systems” (3). See: www.Stockholmresilience.su.se. 
Secondly, the passage assumes a natural division between those who rule, and those who are to be ruled-with second-rate humans, or domesticated animals such as ox, serving as such servants (Politics II.2, 1252b9-11). This view rearticulates the kind of problematic ontological hierarchy that has wreaked havoc on our world through the proliferation of inequalities at all levels of life.

Despite these problems, the passage also holds remarkable promise in determining that the starting-points of the polis are rooted in natural collaboration, even between different species (such as humans and domesticated animals), and holding that without such collaborations survival would be impossible. Furthermore, Aristotle states that it is better for all (domesticated) animals to be ruled by human beings, "since this will secure their safety" (Politics I.5, 1254b12). In these passages, Aristotle's focus on anthropo-zoo-communities is worthwhile, certainly in appreciating the presumed trust and care that humans could offer animals (Despret, $2004,131){ }^{32}$

These thoughts about anthropo-zoo-communities necessitate radical expansion and revision for effective application in our age. In order to foster the kind of vertical transcendence that allows natural beings the chance to realize themselves, humans have to make use of nature's horizontal transcendence to offer ways of rescuing and conserving nature's vertical potentialities. However, to truly grasp the potentiality of physis, a radical overhaul of the political system and its human-nature opposition has to take place. Distorted images such as that of Russian president Vladimir Putin - the ultimate "mother crane" (Van Dooren, 2014, 121)flying in an airplane "teaching" cranes to migrate need to be replaced by a new politics of nature, ideally characterized by an "art of governing without mastery" (Latour, 2004, 235). The aim is here for a social-ecological collective that is nonhierarchical and promotes the plural-natures-and not nature, and that sees humans as $a$-and not as the essential-part of the whole.

It is difficult to envision what such a politics of nature looks like, and to attempt to do so goes beyond Aristotle's ideas on physis and politics. But by holding up Aristotle's idea of physis as a worthwhile goal-nature folding back upon itself and embracing itself-we have an important tool with which to criticize current practices that seemingly restore physis but instead hold species captive "at the edge of extinction" (Van Dooren, 2014, 122). Van Dooren describes the case of Whooping Cranes, one of North America's most endangered birds, their population plummeting at the beginning of the $20^{\text {th }}$ century to less than twenty birds (Van Dooren, 2014, 89, 90). To prevent extinction, captive breeding programs and facilities have been opened in both the US and Canada, "both to ensure the maintenance of valuable genetic diversity in captivity and to produce young birds who might be released in an effort to establish additional self-sustaining, free-living populations" (Van Dooren, 2014, 90).

These facilities do not only provide programs to breed the population through artificial insemination and hatching, but also include training techniques

32 Even more poignantly, we could perhaps speak with Despret of Aristotle being sensitive to both humans and animals performing in a practice that constructs both animal and human: anthropo-zoo-genesis (Despret, 2004, 122). 
that teach Whooping Cranes to migrate, since keeping them captive means that they have not been taught by their parents to migrate. And it is here where miraculous images come to mind of humans successfully leading cranes in migratory flights.

However, the hope and success this story exudes stands in sharp contrast to some of the near-surreal circumstances and concrete suffering that precedes and underlies such "successful" flights. For instance, many of the birds raised in such centers are "costume reared" by humans dressed as birds, and some cranes are exposed to ongoing stresses such as violent restraint for the purposes of either collecting semen or insemination (Van Dooren, 2014, 91, 110).

The vertical transcendence of physis that Aristotle one day envisioned seems far removed from the reality of this conservation practice. Sure enough, the "genetic potential" of these cranes might be preserved, and even their ability to migrate, but in what aspect of their lives is the potential of these cranes truly preserved, coming full circle, radically being cranes? Can this happen if they live outside the care of their parents, are reared by humans in bird-costumes and may never know what it is like to be a parent to their own chick (Van Dooren, 2014, 94)?33 By investigating the dark side of so-called successful conservation stories, we will be offered a chance to re-imagine and re-embody a possible rebirth of physis.

The only way forward, I imagine, is to turn back and reimagine and reconceive a new beginning: one focused on natural, material potencies at the expense of pre-established actualities, and one that sees nature as collaboratively designed and framed within a non-hierarchal politics of nature. For this rebirth and regeneration to happen, much has to change, and much has to be learned. But only then can we start dreaming again of true moments of vertical transcendence: moments where we confidently cross out the idea of the "eternity of the species" and make room for purely infinite moments of transcendence and compassion, where nature folds back upon itself and is constantly regenerated, in solidarity with others.

${ }^{33}$ As Van Dooren writes: "in most cases, captive Whooping Cranes have not been involved at all in the rearing of their young, many deemed to be inexperienced or poor parents who have in some cases failed to properly incubate or have even broken their own eggs" (Van Dooren, 2014, 94). 


\section{Bibliography}

Aristotle. 1979. Aristotle's Metaphysics. Trans. H.G. Apostle. Grinnell: The Peripatetic Press.

Aristotle. 1984. Magna Moralia. In Aristotle, The Complete Works of Aristotle, ed. J. Barnes. Princeton: Princeton University Press.

Aristotle. [1936] 1995. On the Soul. Trans. W.S. Hett. Cambridge: Harvard University Press.

Aristotle. 1998. Aristotle's Physics: A Guided Study. Trans. J. Sachs. New Brunswick/London: Rutgers University Press.

Aristotle. 1998. In Physics, ed. W. D. Ross. Oxford: Oxford University Press.

Aristotle. 1999. Aristotle's Metaphysics. Trans. J. Sachs. Santa Fe: Green Lion Press.

Aristotle. 2001. On the Soul and On Memory and Recollection. Trans. J. Sachs. Santa Fe: Green Lion Press.

Aristotle. 2012. Politics. Trans. C.D.C. Reeve. Indianapolis: Hackett Publishing Company.

Agamben, Giorgio. 1998. Homo Sacer: Sovereign Power and Bare Life. Trans. Daniel Heller-Roazen. Stanford: Stanford University Press.

Agamben, Giorgio.1999. Potentialities: Collected Essays in Philosophy. Trans. Daniel Heller-Roazen Stanford: Stanford University Press.

Baracchi, Claudia. 2008. Aristotle's Ethics as First Philosophy. Cambridge: Cambridge University Press.

Brogan, Walter A. 2006. The Intractable Relationship of Physis and Technē. In Heidegger and the Greeks: Interpretive Essays, ed. Drew Hyland \& John Panteleimon Manoussakis. Bloomington-Indianapolis: Indiana University Press.

Costache, Adrian. 2016. Gadamer and the Question of Understanding: Between Heidegger and Derrida. Lanham: Lexington Books.

Cronon, William. 1996. Uncommon Ground: Rethinking the Human Place in Nature. New York: W.W. Norton \& Co.

Derrida, Jacques. 2005. Rogues: Two Essays on Reason. Stanford: Stanford University Press.

Despret, Vinciane. 2004. The Body We Care For: Figures of Anthropo-Zoo-Genesis. Body and Society 10 (2-3): 111-34.

Foley, Jonathan. 2013. It's Time to Rethink America's Corn System. Scientific American. https://www.scientificamerican.com/article/time-to-rethink-corn/. Accessed 9 May 2017.

Foster, Susan. 2002. Aristotle and the Environment. Environmental Ethics 24(4), 409-428.

Gadamer, Hans-Georg. 1980. Dialogue and Dialectic: Eight Hermeneutical Studies on Plato. New Haven: Yale University Press.

Ginsberg et al. 2014. Synthetic Aesthetics. Cambridge: MIT Press

Goodall, Jane, Gary McAvoy, and Gail E. Hudson. 2005. Harvest for Hope: A Guide to Mindful Eating. New York: Warner Books.

Grosz, Elizabeth A. 1999. Becomings: Explorations in Time, Memory, and Futures. Ithaca: Cornell University Press. 
Hadot, Pierre. 2006. The Veil of Isis: An Essay on the History of the Idea of Nature. Trans. M. Chase. Cambridge: Harvard University Press

Heidegger, Martin. 1998. On the Essence and Concept of Physis in Aristotle's Physics:

B.1. In Pathmarks, ed. W. McNeill, 183-238. Cambridge: Cambridge University Press.

Heidegger, Martin. 1977. The Question Concerning Technology. In Basic Writings, ed. D.F. Krell, trans. W. Lovitt, 307-342. New York: Harper \& Row.

Heidegger, Martin. 1977. Building, Dwelling, Thinking: Heidegger, M. In Basic

Writings, ed. D.F. Krell, trans. W. Lovitt. New York: Harper \& Row.

Higgs, Eric. 2003. Nature by Design: People, Natural Process, and Ecological Restoration. Cambridge: MIT Press.

Höffe, Otto. 2003. Aristotle. Trans. C. Salazar. Albany: SUNY Press.

Kant, Immanuel. 1987. Critique of Judgment. Trans. Werner S. Pluhar. Indianapolis: Hackett Pub. Co.

Latour, Bruno. 2004. Politics of Nature: How to Bring the Sciences into Democracy. Cambridge: Harvard University Press.

Oele, Marjolein. 2018. Aristotle on Physis: Analyzing the Inner Ambiguities and Transgression of Nature. In Companion to Ancient Philosophy, ed. Eric Sanday \& Sean Kirkland. Evanston: Northwestern University Press.

Ramirez, K.S., Jonathan W.Leff, Albert Barberán, Scott Thomas Bates, Jason Betley, Thomas W. Crowther, Eugene F. Kelly, Emily E. Oldfield, E. Ashley Shaw, Christopher Steenbock, Mark A. Bradford, Diana H.Wall, Noah Fierer. 2014. Biogeographic Patterns Below Ground Diversity in New York City's Central Park Are Similar to Those Observed Globally. In Proceedings: Royal Society of London B. 281.

Sallis, John. 1994. Stone. Bloomington: Indiana University Press.

Society for Ecological Restoration. 2002. Official definition. www.ser.org. Accessed 9 May 2017.

Spirn, Anne W. 1996. Constructing Nature. In Uncommon Ground : Rethinking the Human Place in Nature, ed. William Cronon. New York: W.W. Norton \& Co.

Stockholm Resistance Centre. 2015. Applying Resilience Thinking. http://www.stockholmresilience.org/research/research-news/2015-02-19applying-resilience-thinking.html. Accessed 9 May 2017.

Sustainable Table. 2017. Industrial Crop Production. http://www.sustainabletable.org/804/industrial-crop-production. Accessed 9 May 2017.

Van Dooren, Thom. 2014. Flight Ways: Life and Loss at the Edge of Extinction. New York: Columbia University Press.

Ward, Julie K. 2005. Aristotle on Physis: Human Nature in the Ethics and Politics. Polis: The Journal of the Society for Greek Political Thought. 22, (2): 287-308.

Wieland, W. 1970. Die aristotelische Physik. Göttingen: VandenHoeck \& Ruprecht. Xenophon.1994. Oeconomicus: A Social and Historical Commentary. Trans. Sarah B. Pomeroy. Oxford: Clarendon Press. 